\title{
DR. MOBERLY'S THEORY OF THE ATONEMENT.
}

No one acquainted with the prevalent tone and temper of theological thought in this country, within the Church of England as well as outside it, can doubt that an enormous but singularly silent revolution has taken place in the current conceptions of the Atonement. Especially impenetrable has been the reserve of those who may be considered the representatives or successors of the Tractarian school. In official pronouncements, in formal theological teaching, as well as in the pulpit, the Gospel of the Incarnation has practically to a very large extent taken the place of the doctrine of the Atonement. Undoubtedly it is impossible to enunciate a doctrine of the Incarnation, it is impossible to preach Christ in any form, without implying some doctrine of the Atonement. But the doctrine has been for the most part implicit rather than explicit. So far as isolated references and the ordinary tone of pulpit teaching (I mean, of the best pulpit teaching) is concerned, it would be quite possible to get the general impression that in the main the views which are commonly associated with such names as Maurice and Robertson had been accepted by the school who are looked upon (even more perhaps than they look upon themselves) as the disciples of Newman and Pusey. In this, as in so much else, there has been a fusion of the two streams of thought to which what we may venture to call the theological revival of the nineteenth century has been mainly due. Yet side by side with the preaching of the Atonement as a revelation of the love and the character of God there has gone a somewhat perfunctory repetition of traditional formulae, which left one in some doubt as to what was really believed on this great subject either by the leaders or by the rank and file of the High Church party. The present writer can hardly remember during the past fifteen or twenty years a sermon 
in which the doctrine of Substitution was distinctly taught, but he : constantly hears language which can hardly be justified if it is to be distinctly rejected. For this silence those who are not in love with the traditional Protestant theology on this matter have every reason to be thankful. The most fundamental revolutions are the most silent ; and, where a position is abandoned without controversy, the abandonment is often more complete than a controversial victory could have secured. A doctrine which has ceased to be preached is for all practical purposes dead. Still, the ghosts of dead doctrines are often troublesome; and those who hold that intellectual clearness has its value, and that a Church is not in a healthy condition which is practically without a Theology, will welcome any indication of an attempt to put an end to the prevalent vagueness on the subject. Such an indication is to be found in the appearance of Dr. Moberly's book. Whatever may be thought of the position which he takes up, it must be admitted. that Atonement and Personality is a serious attempt at theological thinking, and that it demands serious attention, consideration, and discussion. Dr. Moberly is one of the very few Church of England theologians to whom Theology means something more than either ephemeral polemic on the one hand, or biblical and historical learning on the other.

There is one reason for which Dr. Moberly's book may be especially welcomed. It shows a consciousness, such as has too often been lacking in the works of professed theologians on such subjects, that it is impossible to approach them satisfactorily without coming to terms (so to speak) with a number of philo-sophical questions. There are whole libraries of modern theology, especially of Anglican theology (for both Roman Catholic and continental Protestant theologians have usually some philosophical. basis), which betray not the slightest consciousness that they are discussing great problems of human thought, which form the subject of a science or group of sciences called Philosophy, and which have been treated of by some of the greatest intellects of modern Europe. Dr. Moberly does not claim to write as a philosopher; and his book contains little reference either to the great classical systems or to the more recent developments of philosophical thought. But he does appreciate the existence of philosophical problems, and the need of determining one's 
relation to them before one can reach a scientific or rational Theology. To this fact is largely due the great advance which this book exhibits upon any attempt to deal in a formal and systematic way with the doctrine of the Atonement which has been made by any Anglican theologian of late years. The best compliment that can be offered such a book is to subject it to respectful but serious criticism. There is much in it for which we may be heartily thankful, but there is some danger (as it appears to me) lest the authority which it seems in a fair way to acquire may bring back in a subtle and more attenuated form the very ideas which it professes to repudiate; and that is why I venture to set forth some of the difficulties which it raises in my mind. It is impossible to doubt the sincerity and earnestness with which Dr. Moberly attempts to explain the doctrine of the Atonement in such a way as to reconcile it with the imperative demands of Reason and of the moral consciousness. The question is whether he has succeeded. The merely negative character of this inquiry must be my excuse if the task of criticism is undertaken by one who has no pretensions to the theological learning which would enable him to sit in judgement upon a work of theological research. For this reason I say nothing about the interesting and very candid and sympathetic historical Appendix.

I must say a few words to start with as to what may be called Dr. Moberly's method. A theologian who sits down to write a book upon Christian doctrine is not bound to prefix to his work a treatise on New Testament criticism or Inspiration, but he may reasonably be expected to give us some indication of his attitude towards these problems: for it is by his attitude towards them that it will be determined how far his work can be treated as a philosophical discussion of a philosophical subject, and how far it must be looked upon as a more or less ingenious defence of a preconceived theory which really rests (for those who accept it) upon external authority. On this vital question Dr. Moberly has not given us so much as an inkling as to the state of his mind. We can only say that the way in which he uses Scripture approximates to that of the Schoolmen. When the philosophical armour is getting a little thin, he takes refuge in an isolated text, torn apart from the context, without any attempt to ascertain the real mind of it, the intellectual presuppositions, the intellectual 
atmosphere, of its author. Thus texts from St. John's Gospel are cited as carrying with them the authority of our Lord Himself; as though that Gospel could, in every part and every word of it, be regarded not merely as reproducing in a form coloured by much subjective reflection on the part of the author a side of our Lord's teaching which is absent or less prominent in the Synoptists-but as containing the ipsissima verba of His discourses ${ }^{1}$. "The great Baptismal formula' of Mt. xxviii Ig again is cited as 'supremely authoritative,' without the slightest reference to the fact that the language of St. Paul about Baptism, ' in the name' of the Lord Jesus,' and the well-attested employment of such a formula in the early Church, have suggested grave doubts as to whether we have before us in this passage words which really came from the lips of Christ ${ }^{2}$. So again the most obscure of St. Paul's sayings-those which it is most difficult to reconcile alike with his own general line of thought and with the general spirit of the New Testament, the sayings whose form is most visibly coloured by rabbinical habits of thought-are treated as, in their most obvious and literal interpretation, a conclusive and sufficient basis for a whole system of Doctrine, eternally binding upon the Christian Church ${ }^{3}$.

${ }^{2}$ Dr. Moberly quotes for instance John $\times 30-$ not $\times 3^{2}$, as the reference is given by Dr. Moberly-('I and the Father are One') to show that 'it was not indeed obscure to $\mathrm{His}$ consciousness that $\mathrm{He}$, the Incarnate, was all the while something more than $\mathrm{He}$ was as Incarnate' (p. 95). Yet in the same chapter we are told that they are not 'primarily words of revelation as to the timeless relations between the First and the Second Persons of the Eternal Trinity' (p. 107). They are statements 'about the essential truth of the relation of the Incarnate, as Incarnate, to the Eternal ; the relation of Jesus Christ, the Son of Man, to His God and Father-obedient dependence on whom was the Breath of His Life' (p. 108). I find these points of view hard to reconcle. I should add that I do not myself regard it as improbable that the words were actually used by Christ : but I do contend that we cannot (consistently with any critical view of the fourth Gospel) use them to prove facts about the Consciousness of Christ which are not sufficiently attested by the general picture of that consciousness resulting upon the Gospel records as a whole. Understood as they seem to be in the two last passages they satisfy this test : understood in the first sense they do not. John viii $5^{8-a g a i n}$ wrongly given as ix $5^{8}$ by Dr. Moberly, p. 95-seems harder to interpret in accordance with this canon.

${ }^{2} \mathrm{Mr}$. F. C. Conybeare has recently shown that the quotations from Eusebius

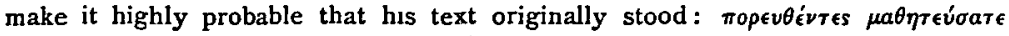

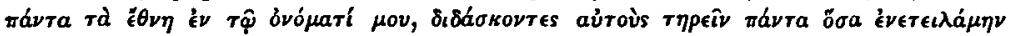
îhv (see his recent paper in Zeitschnifi für die neutestamentlache Wissenschaft, Darmstadt, I902, Heft i).

'E.g. 2 Cor. v 21 ; Gal. ii 13 ; Rom. v $1_{4}$ sq. 
On the particular question of the Atonement Dr. Moberly's implicit deference to the authority of the Councils is of less moment, since fortunately there is little or nothing in their teaching which can be treated as a pronouncement upon the subject; but in the preliminary chapter on the Incarnation we feel that authoritative decisions are employed in a way which postulates that they carry with them not merely authority but absolute infallibility. It is a pity that Dr. Moberly has not indicated the grounds of such a belief and the point at which (if anywhere) Reason has anything to say to the questions with which he deals. We do not of course complain that a Christian theologian, writing for students of Christian theology, should presuppose a general belief in the existence and authority of the Christian Revelation. But we should have liked some indicationhowever slight and incidental-of the meaning which he attaches to Revelation. With the great body even of the more conservative theologians the significance of that word has been, not indeed diminished, but profoundly changed by the results of Biblical criticism, by the study of comparative religion, by the scientific study of Church history, and by many other intellectual influences. It is inconceivable, of course, that a scholar occupying Dr. Moberly's position should be ignorant of this change or of the grounds upon which it rests, or that so acute a mind should have been wholly unaffected by his knowledge: but a reader who had no evidence to go by but the book before us might be excused if he supposed that for Dr. Moberly all that is implied by the phrase 'historical criticism' simply did not exist.

I will give a single instance of the lengths to which our author is prepared to carry his reliance upon authority, and of the extremely arbitrary selection of the authorities to which he defers. If we are to find theological authority anywhere, one would suppose it would be in the writings of the Greek Fathers, contemporary with the great General Councils, who applied the term

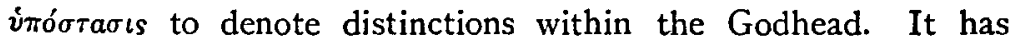
generally been recognised how crude and blundering have been the efforts which Western theology has made to translate into Latin the subtleties of Greek metaphysical thought. It would naturally be supposed that the Greek original possessed more authority than the Latin translation, and that if a Latin word 
is apt to suggest associations which are foreign to its Greek original, the scholarly theologian would carefully warn us against being misled by these associations. Not so Dr. Moberly:-- 'There is something essentially lacking in the word imórtars. And just for this very reason; that, with all its subtle suggestiveness, it is still, so largely, an impersonal word. It is abstract rather than actual, a conception rather than a living whole.... There was after all something positive which was needed; and something which, with whatever lack of full completeness, only the word "Person" really supplied; or had, at least, the capacity of supplying. The word Person has a fulness and totality of meaning of its own, and certainly nothing short of the inclusive completeness of personal being can be predicated, at any moment, of God-whether Father, Son or Holy Ghost' (p. I60). Thus, according to Dr. Moberly, the true doctrine of the Holy Trinity was never really grasped, or at least not expressed, by Basil or the Gregories, but was left to be discovered by the Latin fathers who, with many apologies and many confessions of its unsuitability,

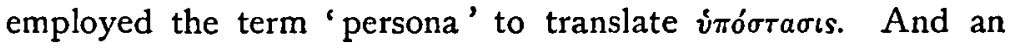
explanation based upon this discovery of the Latins is eternally binding upon the Church! Dr. Moberly might have added that his own doctrine of the Holy Trinity was not yet discovered even by the Latin. framers of the Quicumque vult; for he consistently assumes that the word 'persona' must be held to carry with it all the meanings and associations of the modern 'Personality.' After such a procedure one is not surprised to find that what St. Thomas (if not St. Augustine) gives as a rational, though doubtless inadequate, explanation of the doctrine of the Holy Trinity is somewhat slightingly spoken of as a mere 'analogy.' As far as we can see, the Thomist doctrine of the Holy Trinity is treated as pure Sabellianism.

It is true that in what Dr. Moberly says about the 'mutuality of contemplation, mutuality of love' between the Persons of the Holy Trinity, he could quote much patristic and other authority; but he forgets to take into account the meaning which was attached to the Second Person of the. Holy Trinity by platonizing Fathers and Schoolmen. When the Father is thought of as loving the not yet incarnate Son or Logos, the Logos with many of them stands for the whole of Creation, with all the 
souls that were to be born, as well as the whole scheme of the Incarnation, immanent in the divine Thought. If such language gives to the Logos a distinction which is not that of an 'aspect,' the distinction is very different from that of two 'Persons' in the modern sense of the word. Dr. Moberly uses language which is simply meaningless if we are not to regard each Person of the Holy Trinity as having an intelligence, will, emotions of $\mathrm{His}$ own, however closely in harmony with those of the other two Persons. If such be the true doctrine of the Trinity, St. Augustine's comparisons to the fount, the stream and the water ${ }^{1}$, or St. Thomas' 'power, wisdom and love' would cease to have any truth or validity even as analogies. They would be grossly and irreverently misleading. Dr. Moberly prudently passes very lightly over those phases of the orthodox doctrine which are most capable of a rational interpretation, and least capable of being interpreted in accordance with his views. As is usual with the modern Anglican theologian (the scholastically trained Roman Catholic knows better), Dr. Moberly, when insisting on the separateness of the Persons, always thinks of the relations between the Father and the Son. Since to the popular mind the Son, even before the Incarnation, is mentally envisaged as the pre-existent human Jesus, all that is said on this topic meets with ready acceptance: though we must do Dr. Moberly the justice to say that he is himself quite free from this confusion ${ }^{2}$. But what of the personality of the Holy Spirit? Although a whole chapter is specially devoted to the doctrine of the Holy Spirit, we are left in doubt whether Dr. Moberly would be prepared to condemn as Sabellian St. Augustine's and St. Thomas' doctrine that the love of the Father for the Son is the Holy Ghost. 'There can be no mutual relation between aspects. The heat and the light of flame cannot severally contemplate, and be in love with, one another. Whereas real mutuality-mutuality which involves on both sides personal capacities-is the one thing which we most unflinchingly assert' (p..165). But can we suppose Love-the love of one person for another-to contemplate and be in love with the two persons who love one another? If the word 'aspect' always carries with it

1 St. Augustine employs this as a popular illustration, but he generally prefers the mental analogies upon which the doctrine of St. Thomas is based.

2 See the valuable note on $\mathrm{pp}$. 208-15. 
the suggestion of a characteristic which may be put on and off, which is dependent for its existence upon the caprice of the beholder or the variations in his point of view (which would be really Sabellian), would Dr. Moberly be prepared to describe as a Sabellian explanation of 'Persona' St. Thomas' equivalent 'proprietas'? I will not say that Dr. Moberly, in his anxiety to avoid Sabellianism, falls into Tritheism, but I will say that he would do so but for the fact that all that he says about the distinction of Persons is flatly contradicted by all that he had previously said about the Unity of God: for Dr. Moberly does not deny 'personality' to the God who is One in Three. If therefore the word 'personality' is to be applied also to each Person of the Holy Trinity, surely it must be in a different sense of the word. This is an admission which no disciple of St. Thomas would hesitate to make, but it is never made by Dr. Moberly. Surely a writer who is prepared to ascribe so much authority to Latin theology, and to speak so slightingly of Greek, might have done well to bestow a little more reflection upon the writer who represents the culmination of that development. When Reason and Authority are at issue, one must make up one's mind to choose between them; but such a decision is unnecessary in a matter on which one can have St. Thomas and the Pope on one's side. I will not contend that every technical distinction of St. Thomas lends itself easily to translation into terms of modern thought; but I do unhesitatingly say that his doctrine of the Holy Trinity involves far fewer difficulties than Dr. Moberly's. I can only cordially echo the latter's own aspiration: 'If the thought that wishes to be orthodox had less tendency to become Tri-theistic, the thought that claims to be free would be less Unitarian' (p. 85).

But I will not linger further on what is after all not the main subject of Dr. Moberly's book. I could not go further into it without a full philosophical investigation of the elaborate treatment which the idea of Personality receives at his hands. I will only say that, in the interests of what he takes to be the orthodox doctrine of the Holy Trinity, he seeks to disparage the ideas of separateness and individuality associated with the idea of Personality in ordinary modern language. It is possible that more intimate familiarity with the tendencies of modern metaphysical 
thought (as represented for instance by Dr. Herbert Bradley) might lead him to suspect that he has entered upon a line of thought fatal to any idea of personality either in God or in man. It is painful to see an orthodox theologian playing with ideas, which, taken seriously and followed out consistently, would land him-let me say, to put it mildly-considerably nearer the position of Spinoza than he would wish to find himself. It is a pity that the philosophical equipment of so many of our more thoughtful theologians should often be rather a slight tincture of Hegelianism than a serious study of the one original modern thinker of the very highest rank whose thought is profoundly and without qualification Christian-Hermann Lotze.

But it is time to approach the main argument of the book. Unlike most modern writers upon the Atonement (even one so thorough-going and exhaustive as Ritschl), Dr. Moberly realises that the pre-supposition of any clear and intelligible ideas upon this subject is a clear and consistent idea of the meaning which we attach to such words as Punishment, Satisfaction, Forgiveness, and the like. Up to a certain point it is impossible to desire (if we make allowance for a somewhat exuberant rhetoric which at times obscures his thought) a better or more philosophical treatment of those subjects than is to be found in the introductory chapters of the work before us. They are written with sympathy and spirituality as well as with insight. So long as Dr. Moberly speaks of human punishment, he is emphatic in regarding punishment as a means to an end, as the expression of a love which desires the amendment of the sinner as well as the moral and material good of society, and in rejecting the idea of retributive or vindictive punishment. The theory of 'retributive punishment' which forms the ethical pre-supposition even of Dr. Dale's doctrine of the Atonement is distinctly disallowed. It is admitted, one does not quite see why, that 'both these aspects, the retributive aspect, and the equation aspect, of human justice, belong indeed in fact to human justice; but belong to it not as it is justice, but as it is human; belong, that is, and can be seen directly to belong, to the necessary imperfectness of such corporate and social justice as is possible on earth.' In human justice, it is true 'the individual must be sacrificed to the community.: 
This social purpose of punishment would, however, one would have thought, be put down as preventive or deterrent, and deterrent punishment is not retributive. But at all events Dr. Moberly is quite clear that the object of ideal human justice, in so far as it can afford to think of the criminal only, is not to avenge the past, but to bring the offender to a due sense of his guilt, and so to make him better. Dr. Moberly insists rightly (as it appears to me) upon the meaninglessness of any supposed 'equivalence between sin and punishment.' 'All human punishment . . a aims at, and at least outwardly represents and symbolises, a certain change in the culprit's own personality'that 'change of self which we call penitence' (pp. IO-r I).

So far all seems clear. But then we are suddenly told that, though we always 'begin to punish with a moral intention in respect of the punished, hoping for his amendment, our hopes may utterly fail. More and more, it may be, the depraved man becomes a human tiger. Then we punish, if we have the power, not the less but the more' (pp. II-12). But do we? Or if we do, do we do so for any other reason than the protection and the moral improvement of society? It requires some boldness to maintain that punishment is not originally retributive, and yet that, when punishment is known to be useless for its true purpose, we should go on punishing. Such an astonishing combination of opinions has never, so far as I am aware, been held before ${ }^{1}$. What is the explanation of such a sudden volte-face? It is not far to seek. "We dare not explain away the awful word "Hell," as meaning only a purgatory. We dare not, until the possibility of Hell has been authoritatively explained away, deny the ultimate possibility of the idea of a punishment which is not restorative' (p. 12) ${ }^{2}$.

Here we have a signal instance of the unsatisfactoriness of an argument which is conducted without any explicit indications of its ultimate premisses. What authority would Dr. Moberly recognise as being entitled to 'explain away' everlasting punishment? Would the authority of Reason and Conscience be sufficient? Are Reason and Conscience against the idea of everlasting punishment, in the ordinary sense of punishment, which to Dr. Moberly

'It is true we are told that there was a 'latent retributive character' already (p. 14).

2 There are of course those who would say that punishment is from the first partly retributive and partly something else, but this is not Dr. Moberly's position. 
explicitly means actual pain? It looks very much as if Dr. Moberly would admit that they were, if he were not compelled to the opposite opinion by his deference to authority. And, if they are, would it not be as well to investigate (here he cannot plead that the critical question is irrelevant to his main issue) whether he is quite sufficiently certain of the historical accuracy of a single reported saying of our Lord, of the correctness of the Evangelist's Greek translation of the single Aramaic adjective on which the whole question turns, or of the correctness of the popular interpretation of it, as to feel justified in forcing upon the Christian consciousness a doctrine opposed to the reason and conscience with which God has endowed us, and to the general tenor of that conception of His nature which Christ has revealed to us? Or is some other authority in question? Would it not have been satisfactory to know whether Dr. Moberly can point to a single word in the teaching of St. Paul or St. John, to favour the doctrine of everlasting punishment? Or is it only the authority of the Fathers and the Quicumque vult which is in question? I will not dwell on the subject further, but will merely identify myself with words which I quote, not from Dr. Farrar or Bishop Westcott, but from a writer more in sympathy with Dr. Moberly's presuppositions, though he fully appreciates the distinction between authority and infallibility.

'These statements' [the assertion of endless punishment together with the belief that only a small minority will be saved, to which last of course Dr. Moberly is not committed] 'are difficult to believe, because they imply:

(a) 'The charge against God of amazing cruelty and injustice, such cruelty and injustice as would cover their perpetrator, were he a human being, with ineffaceable infamy, and secure for him the abhorrence of mankind.

$(b)$ 'The failure, to a very great extent, not merely apparent and temporary, but a most real and eternal failure, to redeem and save mankind...

(c) 'That good will never fully overcome evil, and destroy it, but good and evil will be alike everlasting. That God will never fully and finally subdue or reconcile His enemies; but that His enemies and Himself will be eternal together '.'

1 What is the truth as to Everlasting Punishment? pp. 136-7. 
'Is it possible intelligently to believe in Almighty God, and also to believe that His purpose- $\mathrm{His}$ greatest purpose ever made known to us-will be finally, fearfully, everlastingly a failure. That He may work out that purpose to its final issue, its sure accomplishment, by means utterly mysterious to us; that $\mathrm{He}$, with whom "a thousand years are as one day," may be tied by no limit of time in the achievement of what He wills to do - this is conceivable; but that $\mathrm{He}$ should fail finally is inconceivable-inconceivable unless we are prepared to resign our belief in "One God the Father Almighty," and fall back, in company with the ancient heathen, into a dim conception of some "fate" superior to the gods; the darkest and most dismal of all creeds. ... .

'It must, however, never be forgotten that there is nothing like an unbroken chain of evidence, nothing like universal consent ; for from the days of Origen, in the third century, down to our own day, among the innumerable multitude of writers of sermons and commentaries, who have been content, without inquiry, to assume, and then to improve upon, the doctrine of endless misery, there have been here and there thoughtful and learned men, who have not been content so to assume, who have considered and examined a question so full of terrible interest; and again and again the issue of inquiry has been that they have rejected a doctrine which certainly appears to be more utterly and hopelessly dishonouring to God than any other which it is possible to conceive ${ }^{1}$.'

It is obvious that this presupposition of an everlasting Hell must greatly weaken the force of Dr. Moberly's argument for those who cannot attribute to God any punishment not dictated by love, and who cannot ascribe to love the infliction of endless torture which is not to have, and which God knows will not have, any moral result whatever.

But I return to the consideration of his theory on its own merits. Dr. Moberly thus sums up his position:

' For ourselves, in the meanwhile, it is sufficiently clear; (I) that all our punishment presents itself at first to our unreflecting thought under the aspect of retribution, objective and external ; (2) that, on reflection, we recognize that all our punishment has

${ }^{1}$ Ibid. pp. 164-6. 
really the disciplinary motive and meaning; that is, it is really a means so to change personalities which are now potentially righteous but actually sinful, as to make them, in consummated antithesis against sin, actually righteous; (3) that in proportion as our punishment realizes its own meaning, its outward hardness tends to fade into an inner severity of will; retribution more and more is merged in contrition; penal suffering comes ever increasingly to mean the suffering of penance rather than of penalty: but (4) that in proportion as it fails in that essential purpose which made it what it was, it does acquire more and more that simply retributive character, whose climax is not Calvary but Hell' (pp. 23-4).

The theory thus sketched involves not a few difficulties. All that Dr. Moberly says about the repentant criminal's joyful acceptance of his punishment is intelligible enough so long as he is speaking of the sinner imperfectly penitent, who may recognise the value of the discipline, recognise that he is being ' made perfect through suffering,' but Dr. Moberly seems to apply it also to the ideally penitent sinner. One cannot see why, if punishment is simply a means to the getting rid of evil, if it has (as our author uncompromisingly asserts) no expiatory value in itself, the sinner in whom the evil will has already been completely changed should still be punished. It is true, as Dr. Moberly points out, that even the ideally penitent criminal may still have to be punished for social purposes, because human justice 'must think primarily of the effect of its action, not on the criminal but on other men,' and because 'humanity knows no standard by which to try, and has no proper right to accept ' [why not, if the idea of an a priori duty of retributive punishment is abandoned ?], 'perfection of penitence' (p. 20). But all this belongs to the imperfection of human justice: there seems no reason why it should be applied to ideal or divine justice. And a more formidable difficulty remains. We are first told that the retributive or apparently retributive character of human justice belongs to its essential defectiveness, and forms no part of its true character. Why then must God, when the punishment has failed of its purpose, still go on punishing? When that is the case, when the true object of punishment has failed, then God, it would seem, goes on punishing either without an object or for 
an object which is not the true object of punishment. If retributive punishment is not deserved, is not moral, is not reasonable at first, why does it become justifiable and reasonable at last ? Non-retributive, disciplinary punishment is at first inspired by love. By what is it inspired afterwards? I have failed to find a clear and intelligible answer to this question. There seems to be an attempt to answer this question by insisting that 'the punishments of God are what we should call selfacting '-that ' the judgment of God upon sin is but the gradual necessary development, in the consistent sinner, of what sin inherently is.' Sin brings its own punishment 'as death is the necessary consummation of mortal disease' (p. I5). It is no doubt a natural and necessary consummation in accordance with the actual laws of nature. But does Dr. Moberly regard the laws of nature as independent of the will of God? If not, the connexion must surely be capable of rational justification; but it is just the rational justification of a law which makes endless pain the consequence of a sin of which the sinner has ceased to be capable of repenting, which some of us find it difficult to understand. And even if we confine ourselves to the world as it is, can we assert this necessary connexion between sin and pain? Surely it is not in accordance with experience that sin produces pain except $(a)$ in a sinner who recognises its true character, and therefore is partially at least already penitent, or $(b)$ in consequence of some physical effect of the particular sin, which must be in this life supposed to be due to the God-made laws of our present physical nature. That sin should lead to pain may, indeed, be accepted as a necessary feature of a rational order of things. It is what the moral consciousness demands, and the moral consciousness demands it just because in human experience pain is at least the condition of moral improvement. But does the moral consciousness require such a connexion where the improvement is ex hypothesi impossible? Yes, if the retributive theory of punishment be true : No, if (as Dr. Moberly holds) it is false.

I. pass over the difficulties involved in a theory of free-will such as is postulated by Dr. Moberly-a freedom which is capable for ever of resisting the purpose for which the man was made in the image of God. I forbear to ask whether to believe that evil will be eternal does or does not, in the language of the late 
Bishop of Durham, amount to Dualism. I will allow that the idea of a will eternally fixed against good is a possible one. On that hypothesis, a punishment lasting so long as the sinner voluntarily resists God's will may be held to be rational and intelligible-on one condition only, that there is always a possibility of its producing its effect. But why should the punishment continue when, according to the conception of everlasting punishment which Dr. Moberly seems to adopt, moral improvement is impossible? Such a view is intelligible only on the retributive theory of punishment. If Dr. Moberly should reply that it is only in man that retributive punishment is irrational, one may ask once again why what is irrational in man should become rational in God? There might be more possibility of a successful attempt to grapple with these problems if Dr. Moberly were content to limit his conception of everlasting punishment to the poena damni, to the eternal loss of a good which the sinner has once enjoyed, or to an exclusion from blessedness, from the beatific vision (as the Schoolmen would have said), which, though a loss, could not well be felt as pain by the utterly impenitent sinner. But Dr. Moberly insists that punishment must be actual pain. In one place Dr. Moberly says that 'the climax of such a progressive alienation is that incompatibleness with God which we call Hell.' But is this 'incompatibleness with God' intrinsically and necessarily painful, except to those who desire the fuller vision of God, and are therefore partly penitent? Human experience would not seem to suggest that it is so; and, if it is not so by any intrinsic necessity, why should it be made so in a rational universe, unless it serves some purpose? If it does serve a purpose, why does not Dr. Moberly tell us what that purpose is, or may conceivably be? We are only told that it is not mere retribution, for that is a mere feature or apparent feature of the most imperfect human punishment. It is not expiation ; for pain by itself does not expiate. It is not moral improvement; for moral improvement is ex hypothesi impossible. If Dr. Moberly merely accepts on external authority a dogma which fails to commend itself to his own reason and conscience, he would have done well frankly to tell us so. But he attempts to explain, and an explanation ought surely to be intelligibleunless, indeed, that too rests upon authority. 
I pass on to the two chapters upon penitence and forgivenesstwo subjects (especially the last) strangely neglected both by philosophers and theologians. By most professed moral philosophers forgiveness is entirely passed over, except indeed by those who, in their zeal for retributive punishment, would make all forgiveness immoral; while the theologians are generally too much absorbed with the question how forgiveness is to be obtained, to bethink themselves of the necessity of telling us what indeed it is. These chapters are to my mind the most admirable in the book. They breathe a real insight into the Christian ideal of life. I shall not attempt to analyse their contents. It must suffice to give their gist in so far as they bear upon the main argument. Dr. Moberly insists much upon the difficulty of true penitence, upon the necessary imperfection of all human penitence. Ideal penitence is not reached until there is complete identification of the will with God. There is some discussion as to how far penitence can be said really to do away with or cancel the guilt of the past. As far as I understand Dr. Moberly, true or idcal penitence would do this: "Penitence is really restorative. Its tendency is towards what might truly be called "redeeming" or "atoning." It would really mean in me, if only it could be consummated quite perfectly, a real re-identification with the Law and the Life of righteousness' (p. 4I) '. Imperfect human penitence does not accomplish this atonement: for, just because it is imperfect, that implies that some of the evil will, some effect of the past sin, still remains in the present character of the sinner. How far then can punishment or suffering be said to undo or cancel the past? And here I feel still greater difficulty in putting together Dr. Moberly's various statements on the subject. $\mathrm{He}$ is quite clear in laying down that mere endurance of pain as such, mere externally inflicted torture, has no such effect. When the sinner recognises the justice of his punishment, identifies himself with it, and patiently accepts it, then indeed, it seems to be suggested, it does contribute to this result. But this perfect penitence, 'the consummation of penitential holiness-itself, by inherent character, the one conceivable atonement for sin,would be possible only to the absolutely sinless' (p. 43). It

1 But this doctrine seems hard to reconcile with a sentence at the bottom of p. 34 where Dr. Moberly seems to say just the opposite.

VOL. III. 
would seem to follow, and it seems to be suggested by Dr. Moberily, that that perfect identification with the suffering for sin which is to help towards this result is likewise only possible to the perfectly penitent, and therefore only to the sinless. I postpone all criticism upon the theological use which we shall find Dr. Moberly hereafter making of this doctrine. For the present; I will only emphasise the difficulty I have already suggested. In the imperfectly penitent person it is intelligible why suffering, acknowledged and felt as due to his guilt, should have, in . a sense, the effect of undoing the past, for it tends to make his will really better. But what can it do for the man whose repentance is ex hypothesi ideally perfect? On the retributive theory punishment is still due for the past, though there is no good result which it will effect in the present. In saying that the ideally penitent ought still to be punished, Dr. Moberly seems to endorse that theory. Here again Dr. Moberly, the moment he becomes theological, or is preparing to become theological, seems to fall back upon a view of punishment which, as an ethical doctrine, he professes to have abandoned.

The chapter on forgiveness, admirable as in many ways it is, is difficult to summarise-for here (as elsewhere) Dr. Moberly fails actually to develop the conclusions to which his argument seems to point-but I trust I am not doing him an injustice by stating his position thus. The idea that forgiveness necessarily implies remission of punishment is inadequate. On the one hand remission of punishment sometimes falls short of forgiveness. It is possible to say ' I will not punish you-but I can never forgive': the man who remits a penalty but still hates has not forgiven. On the other hand it is quite possible to forgive and yet to punish. Whether punishment is remitted or inflicted must depend upon circumstances. It will be determined (so far as the interests of others allow) by a regard to the true good of the offender, which may now enjoin and now forbid the partial or entire remission of penalty. Punishment can never morally be remitted when it might morally have been inflicted, or inflicted where it might morally have been remitted. There can be nothing capricious or arbitrary about true forgiveness. Forgiveness is only made possible by the forgivableness of the offender. It implies a restoration of the attitude of person towards person, 
which was altered by the wrong-doing: And this restoration is only morally possible where there is some penitence on the part of the offender. The penitence may be very imperfect; there the forgiveness (with or without remission) may be bestowed as a means to greater penitence. There is no pretending that, the offence has not been committed, or that the offender is other than what he is. Ideal forgiveness is simply the attitude of love (which includes due hatred of the sin) in the form which it assumes towards one who has done wrong but has repented of the wrong. The nature of that attitude and its exact manifestation, in the way of remitted penalty or otherwise, will depend upon the amount and the nature of the offender's penitence. 'It is not consummated perfectly till the culprit is righteous : and love does but pour itself out to welcome and to crown what is already the verdict of righteousness and truth ' (p.' 6I). I am conscious that $I$ am here defining a little further than Dr. Moberly has defined: but such seems to me the conception of forgiveness to which Dr. Moberly points. If it is so, it is one which I can heartily accept.

In the next chapter upon 'The Person of the Mediator' the writer approaches his main subject. I have already touched upon his treatment of the doctrine of the Holy Trinity, and will not enter upon that matter again. I shall confine myself to so much of the chapter as directly bears upon the doctrine of the Atonement itself, merely observing that I approach his treatment of it from the point of view of one who shares with him the belief in the divine nature of Jesus Christ, though, it may be, unable to accept much which Dr. Moberly would regard as involved in that doctrine. I have found it, I own, exceedingly difficult to extract from this and from the following chapters any one consistent line of thought; and the only way in which I find it possible to expound Dr. Moberly's position, is to examine separately each of the distinct lines of thought which are combined in Dr. Moberly's theory. Of course I do not mean to say that he is bound to find any one single meaning in a great doctrine like that of the Atonement. On the contrary there would be a considerable presumption against any treatment of the subject which failed to recognise that it represents many truths. Nor do I 


\section{I96 THE JOURNAL OF THEOLOGICAL STUDIES}

suggest that Dr. Moberly's theories are actually inconsistent with one another. What does make our task difficult is the writer's tendency to fly off from one to another. As the difficulties of one point of view become apparent, he half-abandons it and hurries on to another, the deficiencies of which are in turn eked out by running on to yet another, or doubling back to the first. It is quite possible that each of these views may be true, and so a part or aspect of the whole truth. What I cannot acquiesce in is the view that a number of theories, each of them by itself indefensible and untrue,can collectively amount to the truth and the whole truth, except, indeed, in the rather technical sense in which philosophers may hold that every truth that is less than the whole is partial untruth. This is a presupposition which perhaps Dr. Moberly will not share, for (we are told) that 'if two truths, which intellect imperfectly correlates, are nevertheless to be really held together, they are best held not by a refusal to affirm either positively, for fear of interfering with the other, but by a fearless assertion, in its turn, of each' (p. 85). No words could better describe Dr. Moberly's own method. As practical advice to the commonsense thinker, and especially in the region of practical or religious thought, the maxim has its value. But that is just because common sense does of necessity imperfectly correlate the various aspects of truth. But it is the business of the philosopher (and in my simplicity I should have supposed of the theologian also) to effect this 'correlation.' How far this is done by Dr. Moberly, we shall hereafter examine. Meanwhile, I content myself with saying that these criticisms are written from the point of view of one who holds that the principle of contradiction is not yet an exploded superstition ${ }^{1}$.

(I) The first line of thought which can be traced in these

${ }^{1}$ Lest my phlosophy should be pronounced out of date, I will fortify myself with a quotation from an Hegehan writer of acknowledged power: 'Hegel has taught us that the contradictions which the abstract understanding finds in an idea may be due to the idea being too concrete, that is, too true, to be adequately measured by the abstract terms of merely formal thought. But a contradiction is very far from being a sign of truth. On the contrary, as Hegel fully recognised, an unreconciled contradiction is a sign of error,' McTaggart, Studies in Hegelian Cosmology, p. 23. It is merely the 'abstract understanding' which is accused by Hegelians of self-contradiction or inconsistency, not (as with Dr. Moberly) 'Intellect' itself. 
chapters is the one which regards the Atonement as really making men better. It declines to separate the death of Christ from His life. The whole work of Christ has lifted humanity to a higher level, has set before it a new ideal, has awakened a penitence which nothing else could do, and so has really taken away, and still takes away, sin in proportion as the sinner appropriates to himself the saving efficacy which is always potentially there. The suffering, including and culminating in the final agony and death, is an incident and a necessary part of this work. By exhibiting the faithfulness of Jesus to $\mathrm{His}$ vocation, His perfect obedience to His Father, it constitutes an essential part of the manifestation of His character. For those to whom that character is the perfect revelation of God, the suffering is therefore an essential element in the revelation of God's love. And the sympathy which was shown in the voluntary bearing of suffering by the unique Son of God, touches the heart, moves repentance, inspires confidence, and makes possible the approach to God. In all this I am using my own language, not Dr. Moberly's. But this line of thought seems to be implied by all that he says about the possibility of similar saving influences being exercised in limited ways by one ordinary man over another :

- 'Consider, then, the case of a man in whose character we may happen to be interested very closely, and whose character is unmistakably bad. The daily hope and prayer in respect of him is that he may not be that which he is, and may become what he is not. But what is to be done? One thing is plain from the first. He must not be simply left alone. To leave him wholly to himself is to abandon hope. Instinctively you rather ask, who is there about him? has he a mother? a sister? a high-principled companion? a really good friend? If he has; there, you say at once, is the point of hope. Everything will probably turn upon that friend. And then comes the second thought; yes, but if parent, sister, friend, is to be his salvation, to be the living lever whereby he is himself really to become the very thing he is not, it will be no light task, no light pain, for the saving friend. What heaviness of heart there must first be,' \&c. (p. 75).

'It is not a friend who will lecture, so much as a friend who will bear; not a friend who is ready to separate himself 
from, but a friend who is willing himself to enter into, the shadow of the cloud of misery and $\sin ^{\prime}$ (p. 76).

These extracts represent the view which, though every age of Christian thought has borne witness to it, may, as a formulated theory, be conveniently associated with the name of its great mediaeval champion, Abelard, and it is one with which I am in the fullest sympathy. I can only desiderate a fuller and more complete exposition of it. Dr. Moberly, I may add, does fairly ample justice to Abelard in his historical supplement.

(2) From the idea of the saving influence of suffering borne on behalf of another ( $i \pi \epsilon^{\prime} \rho$ ) which may even be called vicarious suffering, since it works for the salvation of the sinner in lieu of and no less effectually than suffering of his own, Dr. Moberly subtly passes to the idea of a punishment borne in the place of another $(a \nu \tau i)$. This is the old idea of vicarious punishment pure and simple. There are, indeed, many apologies, qualifications, explanations, reservations, admissions, distinctions. In one place we are told 'that it is only with the greatest caution, and exactitude of definition, that the word "punishment" can be safely applied to the atoning sufferings of Christ' (p. 23). But if the following passages mean anything at all, they mean vicarious punishment-the old Protestant but wholly uncatholic doctrine ${ }^{1}$; though the 'caution' in Dr. Moberly's treatment is perhaps more obvious than the 'exactitude of definition':

'On the one side, we should recognize at least that there might be cases, in which, if no one could exactly be a substitute for the guilty, yet at least some could more nearly approach to being so than others. It is something to recognize that the impossibility is not, in all cases, absolute and equal : that there are at least degrees of impossibility. Degrees of impossibility imply, at least ideally, degrees of possibility also. A stranger, hired for money to undergo a loss of limb or liberty, would always be an insult to true equity. But one who was very closely identified with the wrong-doer in condition, or blood, or affection; a tribesman dedicating himself for a tribal wrong; the

\footnotetext{
'It is true that the accepted 'Catholic' term 'Satisfaction' seems to mean much the same thing at bottom : but it is vaguer and free from some of the coarsest associations of 'Vicarious Punishment.'
} 
willing representative of a conquered nation, or army ; the father, on behalf of his own child; the husband, for the sake of his wife; is it impossible to conceive circumstances under which a willing acceptance of penalty on the part of some one of these would as truly be the deepest hope of the transformation of the guilty, as it would be the crown of his own nobleness? Imagine, ideally, these three conditions; first that he who so intervened to bear did so at his own most earnest desire, of love; secondly that he was so near to the guilty accused that he might claim a wholly exceptional right to represent him,--near as (under conceivable circumstances) husband might be to wife, or parent to child, or son to father; and thirdly that this sacrifice of vicarious endurance was indeed the truest and the deepest way to produce the contrition and sanctification of the guilty. .. It may be said, perhaps, that of the last two conditions asked for, neither could ever be quite absolutely realized. Between man and man, on earth, they probably could not. But what we may recognize, even between man and man, is some faint approximation towards-even if never, or even nearly, a realization of-the conditions under which vicarious penalty would be not intelligible only, but the supremest manifestation of righteousness as well as of love ' (pp. 77-9).

Dr. Moberly then contemplates the case where it is the Judge himself who has been wronged (does not this very comparison carry with it the suggestion that sin is a personal wrong or indignity suffered by God, which lies at the base of some of the most revolting features of the popular theology?) :

'If it is the king's own son who has been maltreated and robbed; and if the king, in a mood of divine insight, truly sees that his free acceptance of this injury in the person of his son, will be the turning-point of the conversion to goodness of the robber, and it may be of a whole district of brigandage; the very closeness of the identification between himself and his son makes possible an equity which, had the son. been a stranger, would have been unrighteous' (p. 79).

In these paragraphs we already seem to see a confusion between the idea of suffering and the idea of penaity. So long as we confine ourselves to the case of earthly justice, it is no doubt possible to conceive of cases in which one person might wish to bear the penalty for another, and in which such an exhibition 
of love might actually move repentance in the offender, and do the work of punishment more effectually than punishment itself. But could such a proceeding really be called punishment or justice? We can hardly say much of the righteousness or the justice of the supposed king, who should allow of such a substitution; but, if we wished to defend his conduct, we should have to say that he remitted the punishment on the condition of a suffering being borne by the innocent person, which could no longer be conceived as punishment at all. If Dr. Moberly were willing to accept this distinction, we should have no objection to admitting his illustration: but it must be remembered that, in so far as the penalty which would otherwise have been inflicted is conceived of as intended for the moral improvement of the offender, and the substitution is allowed simply as a means to effecting that improvement in another way, we have here only a particular case of suffering on behalf of another, of suffering which produces a real good in the sinner. But we are already afraid that Dr. Moberly intends by this illustration to smuggle back the grossly immoral idea of a retributive punishment which by some a priori moral necessity has to be endured, but which may nevertheless be transferred from the guilty person to the innocent-ideas which in his treatment of punishment he professes to have abandoned. The subsequent course of Dr. Moberly's argument shows us that these fears are not groundless.

(3) But Dr. Moberly himself feels that to justify such a substitution, or at least to justify our saying that in the human parallel which he suggests the penalty has really in some sense been borne by the offender himself, a much closer identification of the offender with his substitute is required than is afforded by any human relationship. Here he passes to that mode of thought which regards the penalty borne by Christ as having been suffered by every individual sinner because it has been suffered by One in whom the whole of humanity was somehow summed up, included, represented. This is the mode of thought which may be traced first of all in the crude, vague, shifting idea of 'recapitulatio' in Irenaeus, and which was afterwards developed into a metaphysical theory at the hands of Fathers and Schoolmen 
.whose minds were steeped in the crudest form of a realism which, though derived from Plato, it would be an insult to call Platonic. Christ's 'relation to the race,' says Dr. Moberly, 'was not a differentiating relation, but a consummating relation. He was not generically, but inclusively, man' (p. 86). 'The only relation which can at all directly compare with it, is that of Adam' (whom Dr. Moberly apparently thinks of as an historical person), 'who, in a real-though a primarily external, and therefore inadequate-sense, was Humanity' (p. 88).

On this theory I would make three remarks :

(a) In what Dr. Moberly says about our Lord's 'inclusive humanity,' when he says 'His relation to the human race is not that $\mathrm{He}$ was another specimen, differing, by being another, from everyone except Himself,' he seems to approximate to that position, so often reached by mediaeval theology, which made Christ not a real human being at all, but a mere metaphysical entity which had somehow got incarnated in a human body. If we really pressed Dr. Moberly's language, it would not be difficult to convict him of the heresy known as Nihilianism, which, just because Christ was humanity at large, denied that He was a man at all ('Christus secundum carnem fuit nihil'). Does Dr. Moberly really mean to tell us, not as a rhetorical flourish, but as a sober piece of historical or psychological fact, that Christ was not one specimen of the human race, 'differing, by being another, from everyone except Himself'? When St. John leant on Jesus' breast at supper, does Dr. Moberly really mean to say that there were not two men there, but only one? If he does not, he really ought not to indulge in this sort of rhetoric, when he professes to be writing a philosophicotheological book. Personally, I have no taste for such exaggeration even in the pulpit. Whatever Christ was more than man, He surely was a man as much as any other. If Dr. Moberly denies this, he not only comes very near to Eutychianism or Apollinarianism, but he separates himself from all that is best, all that is most truly religious and most spiritually effective, in the thought of his own age-the most rigidly and scrupulously orthodox thought as well as any to which might be applied the epithet of 'liberal.' If I wanted to find words in which to correct such one-sidedness, I should turn to the writings of Dr. Gore 
or Mr. Ottley. Dr. Moberly, in short, substitutes a metaphysical Christ for the Christ of history.

(b) The theory is only intelligible on the basis of a metaphysical Realism which I cannot suppose Dr. Moberly seriously to hold. If humanity is to be thought of as having a concrete real existence apart from the individual persons who are human, it may be that the whole of humanity can be said to have suffered the punishment due to their sins, because Christ, in whom all humanity was included, suffered. It may $b e$, because, when we start with a theory which is unintelligible, it is difficult to say what may or may not be logically deduced from it: but even upon these premisses it is difficult to see why the whole of humanity should be supposed to be present in Christ any more than in any other specimen of the race. The ideal of humanity is another matter: but a bad man or a savage is still a man. To insist upon the moral solidarity of the human race, upon the dependence of every man for his very being upon his social relations, upon the closeness of the moral and spiritual relation between Christ and the whole race which $\mathrm{He}$ has redeemed, upon the mystical moral or spiritual (not physical or metaphysical) union between Christ and His Church-all these considerations are nothing to the point. The question is whether we can really say that all men suffered because Christ suffered. In Dr. Moberly's own words, we can only say 'There is, and there can be, no sucii thing as impersonal humanity:' A Universal taken apart from the particulars is not personal or real ${ }^{1}$.

\footnotetext{
1 If it were worth while to subject so loose a theory to serious metaphysical examination, we might point out that if we adhere to the old conception which made the genus include all the properties common to all its species and to all individuals in each, the whole of Humanity (if the word 'whole' can be applied to an abstraction) is present in every individual. Or if (with modern logicians) we hold that the true conception of the Universal includes not merely those characteristics which every individual of the class possesses but all the specific, perhaps even the individual, modifications of which it is capable, then the 'whole of Humanity' was not present in Christ. The Universal Man is not a passionless being because different men have different passions : it has all the passions of uncivilised men and civilised men, of bad men and good men : the concept includes the possibility and actual existence of both species. The Universal Man is not a colourless animal, but one who may be black or white or yellow. All universals are abstractions, but the 'humanitas' of mediaeval thought is the abstraction of an abstraction. I may remark incidentally that when he says that 'God is a particular' (p. 83), Dr. Moberly is saying the opposite of what he means. He means a 'singular' term : only a Polytheist could call God a 'particular.'
} 
(c) If we admit the statement, where is the ethical value or justification of such a suffering by humanity in the person of Christ? It was not humanity that sinned and incurred a penalty, but individual men. Humanity may have paid the penalty in Christ ; but individual men did not. And why should 'humanity' pay a penalty? Because justice demands retribution or expiation? But Dr. Moberly has repudiated that theory. Because punishment makes men better? But will such suffering of a penalty by Christ really make men better? We have already given reasons why, if that is what is meant, we should no longer speak of punishment or penalty: and, if that word is removed, we return to the Abelardian theory of the subjective influence of Christ's death upon the sinner, which Dr. Moberly regards as so miserably inadequate.

(4) But there is a fourth theory which may be regarded as the characteristic feature of Dr. Moberly's interpretation. The theories of vicarious punishment and 'recapitulation' are put forward with so many reserves and qualifications and withdrawals that we are after all left in the dark as to whether Dr. Moberly really holds them or is only playing with them. But in the remaining theory we at last encounter something which is apparently regarded as really true-inadequate no doubt as all human thought about the divine nature must be-but literally, and not metaphorically or analogically, true as far as it goes. This is the theory of vicarious penitence. The theory, reduced to plain terms, appears to be that the power of 'sympathetic self-identity with others,' implied in a measure by every human being's sympathy for another's sin, is such that it may be said to amount to penitence for the sins which the man did not commit, and that in the sinless Son of God that penitence reaches such intensity that it becomes available for the sins of all men, and has the same effect as if they had actually repented '.

'Penitence, in the perfectness of its full meaning, is not even conceivably possible, except it be to the personally sinless.

'Is penitence possible to the personally sinless? I should

1 I pass over the argument intended to show that such vicarious penitence is only possible to one who is both God and Man, which runs very much upon the lines of Anselm's theory. 
perhaps be entitled to emphasize in reply each of these two thoughts: the first, that if the perfection of atoning penitence cannot be achieved by the personally sinless, it will become on reflection more and more manifest that it cannot be either achieved or even conceived at all; and the second, that it is just this-the voluntary sin-bearing of the sinless, the selfidentity with righteousness in condemnation of sin of One whose self-identity, though sinless, could take the form of surrender of the self in the very attitude of the ideal penitent, which is, if anything is, vital to the whole history and being of the Gospel, or the Church, of Jesus Christ. But I do not wish to urge anything at this moment from the side of dogmatic authority' (pp. 1 I $7-8$ ).

I will not discuss the question how far the obscurely phrased and evasive formula about 'self-identity with righteousness in condemnation of $\sin ^{\prime}$ ' and the like can be accepted as a fair statement of any doctrine which can be regarded as vital to Christianity, or which has been at all consistently maintained by a consensus of scriptural or patristic or any other authority. I will only say that the doctrine thus stated seems to be a totally different thing from the theory which makes Christ repent of sins which $\mathrm{He}$ has not committed, and which makes this vicarious penitence available by way of atonement for those sins.

How is this surprising doctrine defended? By the same expedient to which I have before referred, of oscillating between two totally different positions. The considerations which establish the one are assumed to have proved the other. The two views which Dr. Moberly (if I may venture to say so) confuses are these:

(a) He tells us that "the law of vicarious suffering or vicarious energy, as a principle running everywhere throughout human life, is not suspended when we pass within the region of consciousness of sin. Others do in fact suffer and sorrow on their reprobate's behalf, not only with their reprobate, but more deeply and keenly than he does or can for himself. Not only, the pain is in their lives, but the shame is in their hearts-in proportion, it may be, to his shamelessness and their love. Nay, more, this reality of shame in them, the product of the near- 
ness of their love, is your strongest element of hope for him" (p. 118 ).

Here we revert to the first of our points of view-the view which explains the. Atonement by the moral effect actually produced upon the heart of the sinner by the work of Christ, including the suffering which was involved in His sympathy for sinners and the whole of His life and death for them. But this is not vicarious penitence, objectively operating to do for the sinner something which no penitence of his own could do. It is only by awakening, and in so far as it does awaken, penitence that such and such-like cases of vicarious suffering have any effect whatever.

But (b) Dr. Moberly goes on to tell us that all human penitence is imperfect. Yes, and in so far as it is imperfect, the sinner surely is not wholly set free from his sin: and, in so far as he is not, why does the fact that Christ's penitence was perfect constitute any ground why his own punishment should be remitted, or why he should be treated by God differently from the way in which he would have been treated had no such sinless sufferer been penitent and suffered on his behalf? There is nothing in all Dr. Moberly's explanations and analogies which helps us to understand this except the constant harping on the idea of the solidarity of the human race ('Are we not, after all, much more of one piece than we are willing to recognize?'), and the inclusion of all humanity in Christ, which takes us back to a point of view, the difficulties of which I have already endeavoured to indicate. Are we really to suppose that, because man was only imperfectly penitent, God would not have treated him in the way that was really best for him (this, we have seen, is, according to Dr. Moberly, the true attitude of pardon), unless the Sinless had achieved a perfect penitence; or that, because the Sinless had achieved that penitence, God will treat him in a way which was not really best for him? This is what seems necessarily to follow from the idea of vicarious penitence; and this would be to fall back upon the crudest form of that popular-orthodox theology of substitution which Dr. Moberly professes to repudiate so heartily.

One of the difficulties which we encounter, in trying to grasp Dr. Moberly's view, is the difficulty of connecting what he says about the efficacy of vicarious penitence with Christ's death. If 
the penitence suffices, whence the need of pain or punishment? Dr. Moberly seems constantly slipping back into the old theory of vicarious punishment. He seems, in fact, to try to bring back the coarser view by associating it with the more refined theory of vicarious penitence, with which it has no real or logical connexion. Perhaps the following passage will serve as well as another to illustrate the connexion in which the death and sufferings of Christ are supposed to stand with $\mathrm{His}$ vicarious penitence :

'If from our point of view, the point of view of the imperfectly penitent, penitence must include meek acceptance of punishment, remember that punishment, so far as it ministers to righteousness, is only itself an element in penitence. What would have been punishment till it became penitence, is, in the perfectly contrite, only as penitence. It is true that penitence is a condition of suffering. The suffering of penitence may quite fairly be termed penal suffering. But whatever suffering is involved in penitence is part of the true penitent's free-will offering of heartwhole condemnation of sin. To the penitent, in proportion as he is perfected, there is no punishment outside his penitence' (p. I 31 ).

It is really very difficult to extract the thought out of this wilderness of words. It sounds very well to talk about punishment being penitence and penitence including punishment. But, surely, if words are to mean anything, penitence is one thing and punishment another. Why then is the perfectly penitent to be still punished-the penitent for another's sin to receive another's punishment? Earlier in the book we were led to believe that penitence might render punishment unnecessary, or (if it was still necessary) this was for the further moral improvement of the offender or the protection of society. This last surely can have no application to the vicarious punishment of Christ. And the idea of retribution had, we supposed, been abandoned. A dim consciousness that something is wanting to the completeness of the theory seems to have induced Dr. Moberly to vary the phrase by talking of disciplinary pain :

'The suffering involved in this is not, in Him, punishment or the terror of punishment; but it is the full realizing, in the personal consciousness, of the truth of $\sin$, and the disciplinary pain of the conquest of sin', \&c. (p. J30). 
In increased perplexity, I would ask, Granted that the full realizing of what $\sin$ is is painful, why does it involve pain with which it seems to have no necessary or intrinsic connexion - the mocking, the crown of thorns, the scourge, the cross? Granted that penitence may be vicarious, how can we talk of discij inary pain, where the sin is another's? Can we talk of the Sinless being disciplined or morally improved by suffering? Can disciplinary pain mean pain which serves as discipline to another? And how can the pain of one serve as discipline to another? That it may move repentance I understand, but that is the view which Dr. Moberly regards as inadequate.

The theory now under examination cannot, it would appear, be supported by any great weight of authority. But it is not new. Dr. Moberly's thought seems in the main derived from McLeod Campbell's earnest and thoughtful book, though he has sought to combine it with various inconsistent theories which that writer distinctly repudiates ${ }^{1}$. Something still more closely resembling Dr. Moberly's theory appears to have been maintained by the Lutheran theologian Haring. And I will conclude my remarks upon it by quoting the words in which Ritschl deals with it :

'According to Haring, the point is that the imperfect repentance wrought by men is completed by an analogous work on Christ's part. This does not imply that Christ Himself repented of sin; for as $\mathrm{He}$ had no personal experience or knowledge of sin, this work is not to be imputed to Him. But Haring thinks it may be assumed that Christ's consciousness in His vocation included the painful knowledge of the opposition of all sin to God, and thus realized the purpose of punishment, which sinners with all their sense of guilt do not perfectly realize. I admit in general that in Christ we have to count upon the purest and tenderest sense of the contrariety of sin to God; but if such a value is to be put on that as is done by Hairing, I expect Scripture proof to be adduced. I regard a construction which entirely dispenses with the latter as unreliable. It arouses a suspicion that the picture of Christ is being touched up at one's own pleasure. ... For we are responsible only for our own sin. It is

' McLeod Campbell entirely gives up the idea of Substitution, and though he contends for a 'retrospective aspect' practically merges it in the 'prospective.' 
therefore a mistaken tendency which gives rise to the requirement of the Pietists, for the sake of which Haring postulates that supplementary work of Christ. As the attribute of guilt cannot be proved to belong to original sin, it is a delusion to expect our own repentance to make itself responsible for sin as a whole. But if it cannot do that, we must not look for any supplement in Christ's infinite grief for sin, which, being in any case different in kind from repentance, can in no way serve as a supplement ${ }^{1}$.'

Oniy one more chapter of Dr. Moberly's book remains which calls for anything like detailed examination for our present purpose; and that is the chapter headed 'Objective and Subjective.' If the reader has followed the preceding line of criticism, he will have observed that wherever we have found Dr. Moberly's analysis of the effect of Christ's work in harmony with the requirements of common sense and ordinary morality, it is some subjective effect that is in question. Wherever we have found his theories difficult to understand, the examination of the reasons alleged for them has always ended either in resolving them into some subjective effect-into the actual penitence, moral renewal, moral enlightenment, moral progress, due to that work-or in finding the real difficulties untouched. No illustration or analogy or argument has really tended to make any of the objective effects claimed for the death of Christ one whit more intelligible than before. That is especially so with regard to Dr. Moberly's most peculiar and characteristic theory-that of vicarious penitence. That the suffering of the Innocent for the sins of the guilty should move a sinner to repentance and amendment, that is intelligible. That this suffering -call it penitence or not-should apart from such effects aid or facilitate a pardon not otherwise possible or justifiable, has been found to be wholly unintelligible. But Dr. Moberly is committed by the orthodox tradition-I mean the tradition of modern orthodox theology, for conciliar authority is absent, patristic authority doubtful and conflicting, biblical authority susceptible of more than one interpretation-to assert an objective effect. And therefore we have a whole chapter headed 'Objective

1 Justification and Reconciliation, Eng. trans. by Mackintosh and Macaulay, pp. 553-4. 
and Subjective.' We might have expected to receive from this chapter some enlightenment as to the way in which it is supposed that the vicarious penitence and the vicarious suffering can benefit us apart from their moral effects upon us. But we are disappointed. All that this argument for an 'objective' atonement comes to is the assertion ( $I$ ) that the death and sufferings of Christ must have actually happened as facts of history before they could produce any effect on us, and (2) that this effect of the Atonement cannot be appropriated apart from the work of the Holy Spirit, and that that work postulates the historical life and death of Christ: 'Calvary is the condition precedent and enabling of Pentecost.' But all this does nothing to support the kind of objective Atonement implied by Dr. Moberly's previous theories. In this sense, who that believes in an atonement at all has ever denied its 'objectivity'? We ought perhaps to notice that the subjective view is combated by the curious argument that the same effects might have resulted 'from an erroneous belief in Calvary and the Ascension, as from a true one, if only the erroneous belief were sufficiently protected from every suspicion of doubt.' If we were to admit that they might, what then? Because God might have produced certain moral effects by causing the general belief in a lie, is that any reason for refusing the mode of redemption which $\mathrm{He}$ has actually provided for us, or for putting upon it an interpretation which Reason and Conscience repudiate? Really Dr. Moberly's argument reminds one of Naaman's 'Are not Abana and Pharpar, rivers of Damascus, better than all the waters of Israel?' and some of the sermons against Scepticism and Rationalism which I have heard preached upon that text.

Surely the means of Redemption provided by God would be no less precious because other means might conceivably have attained the same end. And after all has the idea of the truthfulness of God no place in Dr. Moberly's theology?

Throughout the book there appear to run two great confusions :

i. The confusion between an effect produced upon the character of the sinner and an obliteration of sin or guilt which takes place independently of any such effect.

VOL. III. 
ii. The confusion between the retributive view of punishment and the disciplinary.

In the first case, all the reasoning goes to establish the subjective view, while the objective is surreptitiously introduced into the conclusion. The conclusion seems to be arrived at by assuming that what commends and makes intelligible the first thesis will prove the second. In the second matter, the retributive view of punishment is explicitly rejected, though with the illogical reserve that when punishment fails to produce penitence, it then becomes retributive-a view which Dr. Moberly does not attempt to support by any argument whatever. Yet the whole of Dr. Moberly's argument in support of his actual thesis assumes the retributive view. In short, whenever anything in the traditional view is shocking to the Reason and the moral consciousness, it is repudiated while formally under discussion, but assumed more or less undisguisedly in the subsequent argument.

Criticism is of no use unless it is honest and thorough-going, and therefore I have not hesitated to express freely the difficulties which I have felt with portions of Dr. Moberly's argument. I approached it with the sincere hope of finding in it much that I could admire and learn from. In a sense I have not been disappointed. For it would be possible for me by a cento from Dr. Moberly's pages to express most of what I believe, and even to repudiate most of what $I$ do not believe. There is hardly a passage or an idea to which I have objected, against which I could not adequately protest by some selection from Dr. Moberly's own words. But Dr. Moberly's mind, perhaps owing to the very breadth and catholicity of his sympathies, seems incapable of appreciating the fact that the gulf between fundamentally opposite and inconsistent modes of thought cannot be bridged over by a dexterous turn of phrase. His mind is subtle, but his subtlety sometimes reminds one that there are other kinds of subtlety besides that of the philosophical thinker. In the less controversial parts of his work there is undoubtedly much to admire, and the whole tone of his treatment is immensely in advance of that of some current theological textbooks. It is because they hoped more from it that it will disappoint many who would have been fully prepared to welcome a fresh treatment of the Atonement emanating from the school of which Dr. Moberly is a distinguished 
- representative. For the frankness with which I have spoken I believe I shall be readily pardoned by Dr. Moberly himselfmore readily perhaps than by some of his followers.

I may be asked what theory of the Atonement it is proposed to substitute for those which have been criticised. That is a question which it is quite beyond the compass of this article to answer. The general drift of the treatment which I desiderate has perhaps been sufficiently indicated by the agreement which I have ventured to express with large parts of Dr. Moberly's work. An adequate modern treatment of the subject-at least an English treatment of it-is still much to be desired; but, if $I$ have felt it a duty to introduce a discordant note into the chorus of approbation with which the book has been received, it is largely because I fear it may draw away the attention of theological students from the writings from which they would be able to collect what seem to me more reasonable-I will venture to add, far more worthy and far more reverent-ideas about this great subject, from the writings of Maurice and Westcott and Llewelyn Davies, from the scholarly history of the subject by Nutcombe Oxenham, and above all from the profound and inspiring, if somewhat dry and technical, treatise of Albrecht Ritschl, which has recently been made available for English readers. It is a significant fact that it should be possible for an Oxford Professor of Theology to write an elaborate treatise upon the doctrine of the Atonement without so much as mentioning the name of Ritschl, or alluding to any of the characteristic ideas of a school which has coloured the whole theological thought of modern Germany.

H. RASHDALL. 